\title{
Correction to: Markov Chain Analysis of Rainfall over East Asia: Unusual Frequency, Persistence, and Entropy in the Summer 2020
}

\author{
Yoon-Kyoung Lee ${ }^{1} \cdot$ Hye-Sil Kim ${ }^{1} \cdot$ Jung-Eun Esther Kim ${ }^{1} \cdot$ Yong-Sang Choi ${ }^{1,2} \cdot$ Changhyun Yoo $^{1,2}$ (D)
}

Published online: 9 November 2021

(c) The Author(s) 2021

\section{Correction to: Asia-Pacific Journal of Atmospheric Sciences https://doi.org/10.1007/s13143-021-00255-0}

The article 'Markov Chain Analysis of Rainfall over East Asia: Unusual Frequency, Persistence, and Entropy in the Summer 2020', written by Yoon-Kyoung Lee, Hye-Sil Kim, Jung-Eun Esther Kim, Yong-Sang Choi, Changhyun Yoo, was originally published electronically on the publisher's internet portal on 25 of August 2021 without open access. With the author(s)' decision to opt for Open Choice the copyright of the article changed on 27 of August 2021 to $($ ) The Author(s), 2021 and the article is forthwith distributed under a Creative Commons Attribution 4.0 International License, which permits use, sharing, adaptation, distribution and reproduction in any medium or format, as long as you give appropriate credit to the original author(s) and the source, provide a link to the Creative Commons licence, and indicate if changes were made. The images or other third party material in this article are included in the article's Creative Commons licence, unless indicated otherwise in a credit line to the material. If material is not included in the article's Creative Commons licence and your intended use is not permitted by statutory regulation or exceeds the permitted use, you will need to obtain permission directly from the copyright holder. To view a copy of this licence, visit http://creativecommons.org/licenses/by/4.0.

The original article has been corrected.

Open Access This article is licensed under a Creative Commons Attribution 4.0 International License, which permits use, sharing, adaptation, distribution and reproduction in any medium or format, as long as you give appropriate credit to the original author(s) and the source, provide a link to the Creative Commons licence, and indicate if changes were made. The images or other third party material in this article are included in the article's Creative Commons licence, unless indicated otherwise in a credit line to the material. If material is not included in the article's Creative Commons licence and your intended use is not permitted by statutory regulation or exceeds the permitted use, you will need to obtain permission directly from the copyright holder. To view a copy of this licence, visit http://creativecommons.org/licenses/by/4.0/.

Publisher's Note Springer Nature remains neutral with regard to jurisdictional claims in published maps and institutional affiliations.

The original article can be found online at https://doi.org/10.1007/ s13143-021-00255-0.

Yong-Sang Choi

ysc@ewha.ac.kr

$\triangle$ Changhyun Yoo

cyoo@ewha.ac.kr

1 Center for Climate/Environmental Change Prediction Research, Ewha Womans University, Seoul, South Korea

2 Dept. of Climate and Energy Systems Engineering, Ewha Womans University, Seoul, South Korea 